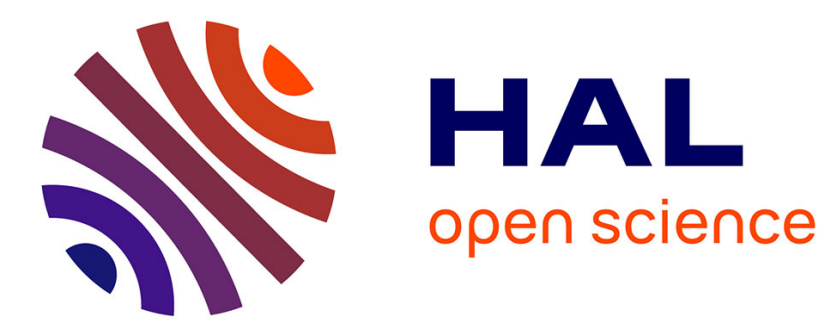

\title{
Strategies of involvement and moral detachment in House of Cards
}

\author{
Sandrine Sorlin
}

\section{To cite this version:}

Sandrine Sorlin. Strategies of involvement and moral detachment in House of Cards. Journal of Literary Semantics, 2018, 47 (1), pp.21-41. 10.1515/jls-2018-0002 . halshs-02486287

\section{HAL Id: halshs-02486287 https://shs.hal.science/halshs-02486287}

Submitted on 20 Feb 2020

HAL is a multi-disciplinary open access archive for the deposit and dissemination of scientific research documents, whether they are published or not. The documents may come from teaching and research institutions in France or abroad, or from public or private research centers.
L'archive ouverte pluridisciplinaire HAL, est destinée au dépôt et à la diffusion de documents scientifiques de niveau recherche, publiés ou non, émanant des établissements d'enseignement et de recherche français ou étrangers, des laboratoires publics ou privés. 


\title{
Strategies of involvement and moral detachment in House of Cards \\ Sandrine Sorlin
}

Univ Paul Valéry Montpellier 3, EMMA, UR 741, F34000, Montpellier, France

\begin{abstract}
The aim of this paper is to evince the reasons why the viewers tend to 'root for the bad guy' in House of Cards in spite of his amoral undertakings. It delves into the linguistic, pragmatic and cognitive strategies employed by the protagonist, Frank Underwood, to 'transport' the audience in the narrative while distancing them from moral judgment. It is shown that the 'Para-Social Relationship' he constructs with the audience invites them to adapt to his goals and perspective, guiding their emotions and reactions, distracting them from ethical matters through generalised impersonalised aphorisms and transgressive humour. Lastly it proposes a three-level model of producing/viewing processes that are specific to House of Cards, highlighting the way the protagonist's manipulation of audience involvement breaks apart in the last seasons, as the production crew alters the Frank-audience relationship.
\end{abstract}

\section{Key words}

Involvement, moral disengagement, stylistics, rhetoric, pragmatics, cognition, parasocial relationship, TV series, House of Cards

Recently a variety of "bad guys" have been at the centre of some American TV series, as in The Sopranos (HBO, 1999-2007) at the turn of the 21 th century, but also House, M.D. (Fox, 2004-2012), Dexter (Showtime, 2006-2013) and Breaking Bad (AMC, 2008-2013) and yet this has not prevented the audience from enjoying the shows. This paper deals with the phenomenon of audience enjoyment of a series featuring an amoral character at its centre, the successful ${ }^{1}$ American political series House of Cards (Netflix 2013-, five seasons to date): the audience ${ }^{2}$ seem to enjoy the show and most of them even seem to root for the cynical, power-hungry, murderous politician, Francis Underwood, whereas moral scruples might be expected to override their enjoyment of the series. Hence the question that this paper will address: how does the main protagonist manage to keep the viewer on his side in spite of his amoral dealings? Of course the success of the series can be accounted for by "exogenous factors" (Brown 2015) such as the popularity of the

\footnotetext{
${ }^{1}$ The success of the series is difficult to measure quantitatively though. For one thing because Netflix is a subscription-based service that is not beholden to advertisers, which makes it difficult to assess the popularity of its shows, all the more so as Netflix rarely reveals its viewer data, so there can only be estimates of how many viewers log (http://www.cnbc.com/2016/03/04/how-many-people-will-bewatching-house-of-cards.html, accessed 17 January 2017). The only thing that can be said is that Netflix has had a steady growth in subscribers and that the series itself won three First Prime Emmys in 2013 and was nominated for 22 Emmy Awards during the first two seasons. Kevin Spacey won a Golden Globe and a Screen Actor's Guild Award for his role as Frank Underwood.

${ }^{2}$ This remark is based on viewers' reactions on internet forums and discussion threads such as http://www.giantbomb.com/forums/off-topic-31/house-of-cards-season-2-discussion-threadspoilers1472254 / as regards season 2 for instance, but of course people giving their opinions on these threads are mostly fans of the series. However their comments on the unequal quality of the following seasons for instance attest to their critical appraisal.
} 
main actor, Kevin Spacey (at least up until October 20173), or the success of the British version of the series (the 4-episode BBC series broadcast at the end of Margaret Thatcher's tenure as Prime Minister in 1990), itself based on Michael Dobbs's novel, House of Cards (1989), thus forming an "aesthetic whole" that could be drawn upon in the American production; or, lastly, the reputation of the director, David Fincher, known for his work in The Social Network (2010) for instance. Furthermore, the theme of the series portraying politics in Congress as one imagines it to be, run by men and women whose sole obsession is their re-election, certainly contributes to creating some "perceived realism" that tends to be positively correlated with the capacity to "hook" the viewer (see Krakowiak and Oliver 2012). But this article chooses to focus on narrativeinternal factors such as the linguistic, rhetorical and narratorial devices employed in the series to manipulate the viewer's attention and perception of events.

It will first be shown that the audience are framed into a (fake) participant role that creates 'rights' and 'duties' for them through the "Para-Social Interaction" it establishes. Section 2 details the strategies of moral disengagement used by the protagonist (and designed by the production crew) to distance the viewer from cognitive scrutiny and moral evaluation. It also highlights the force of his confident rhetoric through the use of specific grammatical and lexical features, humorously mixing registers and genres to deter the audience's attention from his criminal agency. The last section pinpoints how and why the manipulator ends up manipulated as the "collective sender"4 structurally condemns him to failure.

\section{Constructing a "Para-Social Relationship": You and I.}

As in the original British series, the producers of the American version of House of Cards chose to create a peculiar relationship between the audience and the protagonist, Francis Urquhart. Emphasised through the use of direct address to the viewers, it establishes what has been known in the literature for a long time as a 'Para-Social Relationship' (PSR) or 'Para-Social Interaction' (sometimes PSI below) (Merton 1946, Horton \& Wohl 1956) ${ }^{5}$ through which the media performer constructs an enduring bond of intimacy, by sharing intentions, plans, wishes and thoughts with the audience. Although this theory has mainly been used and adapted for the study of non-fictional mediated encounters with mass media performers, originally on television - this might explain why it has not been taken up in narrative studies - I think it can be applied to the fictional interpersonal 'communication' that takes place across the screen in House of Cards. Congressman Frank Understood positions the viewer as a co-player in the plan he has in mind (becoming the next president of the United States). The intimate rapport with the audience is created and sustained through imperatives and questions that connect Underwood directly to them, as in the following example where he shares with

\footnotetext{
${ }^{3}$ In the wake of the Harvey Weinstein scandal (that arose on October 5, 2017), Kevin Spacey was accused of multiple sexual assaults. The day after the first accusation by the actor Anthony Rapp who was 14 at the time of the assault, Netflix announced that its employment of the actor on the sixth series was suspended and declared three days later that it would not be involved with the actor again in any subsequent productions.

${ }^{4}$ I am using Dynel (2011: 1635)'s definition of the "collective sender" as inclusive of the whole production crew (scriptwriters, directors, actors, camera operators, film editors, sound editors, etc.).

${ }^{5}$ The more recent psychological research has focussed on one specific dimension of PSR that is parasocial attachment (Mikulincer and Shaver 2009, Stever 2013).
} 
the viewer what he perceives as the duplicity in the president's Chief-of-Staff's attitude, pretending to ask for the audience's opinion:

Did you smell that? The smugness, the false deference? $(1.1)^{6}$

In what could be called "paracommunication" (Hartmann 2008: 181) in the sense that "the mediated character performs symbolic behaviour towards them and is aware of or at least anticipates their social reactions", the effect of the question here is to pretend that character and viewers share a common ground: it presupposes first that there was smugness and fake deference (existential presupposition) and second that the audience might have noticed these things. Through the rhetorical question (that can be glossed "did you notice Linda's smugness and false deference?"), viewers are thus treated as if they had caught all this, which turns them into fellow insiders, flattering them in the process. This is part of Frank Underwood's way of distinguishing worthy insiders and unimportant outsiders such as the ordinary US citizen. The questions whose answers are contained in the binary formulation also serve to enhance the protagonist's worth:

There are two types of vice presidents: doormats and matadors. Which do you think I intend to be? (2.16)

This "paracommunication" allows the protagonist to give the illusion of responding to the audience's guesses or implications, as when Underwood comments on the Republican couple's children running around the White House in the fourth season: "you guessed it, I still hate children" (4.46) - which is a nod to the faithful audience, in echo of episode 1.9: "I'm not going to lie. I despise children. There, I've said it".

To this must be added the recurrent silent looks of connivance at the camera, often in reaction to what has been confided to the audience before, serving as a comment of the type "see, I told you" or "only you can know what I'm thinking right now". In this specific ontological plane where an illusion of mutual awareness is created in the asides between TV character and audience (see part 3), the protagonist gets viewers out of their traditional invisibility behind the fourth wall, acknowledging their presence as the only participants that are worthy of his confessions. Creating a relation of confidence (based on revelations of plans, thoughts and desires) indeed amounts to constructing the viewer as an accomplice that sets her apart from the other participants (in the story-world). Furthermore, disclosures call for some reciprocity of attention in House of Cards: how can one indeed refuse to follow someone who forces an alliance upon you (apart of course from hitting the off button)? How to disengage from a relationship with someone that considers you as a permanent ally as regards what goes on in the plot? Indeed this positioning of the addressee in the I/you dyad - although one that is non-reciprocal unlike in normal I/you interactions (as highlighted in Benveniste 1966) - is bound to have an influential effect on the audience's attitude. Strongly inviting viewers to occupy the 'you' position in the (non-interactive) dyad, it creates a conversational mode that perforce fosters viewer involvement with the protagonist's plans. It must be said that sharing intimate thoughts with the audience is as old as Shakespeare's soliloquies although the use of the second-person in House of Cards makes the address more explicit than in Richard III for instance when the 'you' is presupposed only by the use of 'I' in asides (see Sorlin 2016: 163, 213, or McIntyre 2008

\footnotetext{
${ }^{6}$ In the quotations from the series, the first figure corresponds to the season and the second to the chapter.
} 
for a study of Ian McKellen's film). PSI encroaches upon the audience's independence, as Horton and Wohl (1956: 219) make clear: "[the audience's independence] is relative in the profound sense that the very act of entering into an interaction with another involves some adaptation to the other's perspectives, if communication is to be achieved at all".

As for Shakespearian villains, the asides serve to draw the audience into the plot: the narratorial 'space' they offer in House of Cards is used by the protagonist to involve the viewer in his quest for success. The use at times of the first person plural attests to this imposed communality of goals: commenting on his attempt at blocking one bold move on the part of his Republican opponent, he urges the participation of the viewer: "Let's kill them with kindness, shall we?" (4.48), taking the audience hostage in his plan as he presupposes their willing participation. As research (Zwaan 1999, Allbritton \& Gerrig 1991, Gerrig 1993) has shown in theories of narrative experience, readers/viewers devote a lot of attention to 'goals and outcomes', expressing preference for a positive over a negative outcome. In House of Cards, the preference for a positive outcome (the success of the protagonist) is guided by Frank Underwood himself who is calling for what Allbritton and Gerrig call a "positive participatory response" ( $p$ response) ${ }^{7}$ that "causes us to focus our attention in a particular way" (Gerrig 1993: 67). He does this in asides by sustaining suspense that is known to provoke great enjoyment, especially when the outcome appears uncertain or the solutions presented fail one after the other, reducing the "space of solutions". ${ }^{8}$ As Egidi and Gerrig (2006) point out, if the character's goals are narrated in an 'urgent', suspenseful manner, the reader is all the more likely to identify with them. This is what Simpson (2014: 4) demonstrates in his study of Alfred Hitchcock's film Psycho (1960), showing that the viewer's following the moment-to-moment experience of the character's ongoing actions is "enough to override the 'good guy/bad guy' schema". In House of Cards, obstacles along the way are foregrounded by the protagonist by means of some linguistic urgency with which he confesses his progress and setbacks: "forward is the battle cry" (1.1) or "Rebellion on all fronts Claire, Zoe, Russo. I must not lose my resolve. I will march forward, even if I have to do so alone" (1.10), assimilating his quest to a battle. The difficulty he faces and the risks he has taken are conveyed through the recurrent structure 'if... then...', which makes his fate dependent on not entirelly controllable hypotheses in game-like bets, as when he hesitates to reveal the president's Chief-of-Staff his desire to be Vice-President.

Francis: I must gamble everything I have right now. If I'm honest, she may use it against me. If I'm not, she won't lift a finger. (1.11)

The viewer is caught in this irrepressible forward march that the protagonist himself represents as a story in one self-reflexive aside: "It's not beginning the story that I fear, it's not knowing how it will end. Everyone is fair game now, including me" (2.23). This

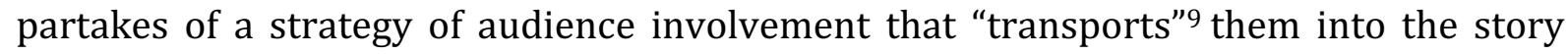

\footnotetext{
${ }^{7}$ Participatory responses (p-responses) depict readers' reactions such as happiness, hopes for the character that she achieves what she has undertaken, or fear when obstacles come her way for instance.

${ }^{8}$ According to Gerrig (1993: 83), the experience of suspense is indeed heightened when it is modelled on a 'problem-solving process': "Readers apparently take great pleasure in the imaginary experience of problem solving. [...] To make the reader really feel suspense, the author must sufficiently constrain the space of possible solutions so that the situation appears beyond hope. [...] As each solution is eliminated, the perception of suspense is heightened."

${ }_{9}^{9}$ Transportation is the process of becoming fully engaged in a narrative world (Green 2004, Green \& Brock 2000, 2002).
} 
world, leaving the end suspensefully unknown and uncertain. As Oatley (1994: 69) indicates, the viewer tends to adopt the player's goal and internalise his perspective as part of the plot-game:

For the same reasons that enjoying a game is based on adopting a goal that the game affords (e.g. to win against an opponent) together with an outline script and resources for accomplishing it, so the essence of enjoying a plot-based story is to take on the goals and plans of a character. A plot is the working out of such plans in the story world.

Working his way out of the most intricate situations in the first two seasons, even when the space of solutions seems dramatically reduced, Frank Underwood projects the image of the superhero overshadowing weaker opponents. Research - specifically focused on fans' relation to their football teams - has proved that aligning with a winning team tends to reflect on one's self-esteem and the image one may have of oneself (Cialdini et al. 1976). Positioned as part of the game, the viewer may find this positive image reflected by a winning game-player gratifying. Following Frank's plan makes them indeed part of the winning team, so the audience may be implicitly led to want what the protagonist wants as part of their 'p-response'.

Underwood makes it therefore all the more difficult for the viewer to disengage from the position of complicity he assigns her, as the working out of his plans is described in a most suspenseful game-like manner that is likely to trigger enjoyment. Indeed this involvement in the plot-based story makes any dis-alignment from the protagonist's plan hard to perform - at least in the first two seasons. Frank Underwood capitalises on the "para-social relationship" he establishes, gratifying the audience as trust-worthy fellow-players in the game to success. Section 2.2 will show how the antihero's self-constructed positive image is linguistically and pragmatically realised. But first one must try to understand better how moral detachment obtains in House of Cards.

\section{Strategies of moral disengagement}

\section{1 'Moral disengagement cues'}

Rapp and Gerrig (2006: 55) mention: "Without any special prompting from the text, readers are likely to prefer what it is 'normal' to desire (e.g. that characters succeed rather than fail)". What makes this preference problematic in House of Cards is that the series does not feature what can be called a 'good guy' but somebody who is ready to commit murders to succeed at all cost. Are these unethical actions 'promptings' from the 'visual' text that are bound to distance the viewers from the protagonist or does their desire to see the protagonist achieve his goal override any scruples they may have? According to Affective-Disposition Theory (Zillmann \& Cantor 1972), morality is placed at the centre of enjoyment and emotional reactions to characters: viewers usually tend to prefer positive outcome for morally good characters and wish for bad characters to fail or to be unhappy in their endeavour. However Raney (2004) has also shown that moral judgment does not always regulate viewers' liking of characters. It seems possible for them to separate what is morally questionable from their dispositions towards the 
protagonist, all the more so if they have been exposed to antihero narratives before. ${ }^{10}$ Here is how Shafer and Raney (2012: 1031) put it: "Through repeated viewing of antihero stories, viewers can learn that plot pattern and develop corresponding cognitive structures that are activated when such stories are later viewed". As mentioned in the introduction, House of Cards does have some precedents of bad guy series. ${ }^{11}$ When watching good shows with morally ambivalent characters, the viewers are likely to develop some defensive strategy in order to avoid what is called "cognitive dissonance" (Festinger 1957) which appears when one experiences stress provoking contradictory beliefs/values that go against humans' striving for consistency. As experiencing cognitive dissonance is bound to hinder enjoyment, if one is willing to continue enjoying the show, some form of moral disengagement must be carried out. In other words, if the viewer is willing to carry on with her p-response, if only to avoid dissonance, she may "put aside moral scrutiny" (Shafer \& Raney 2012: 1037). Experimental research (Hartmann and Vorderer 2010, Krakowiak and Tsay 2011, Shafer and Raney 2012) has shown that moral disengagement is all the more likely to occur if strategies of moral disengagement are cued by the text to guide information processing. Asides in House of Cards are a key space in which justification for the protagonist's immoral acts is provided by the protagonist himself with the aim of preventing deep ethical thinking on the part of the viewer or even their total rejection of him on moral grounds, and preserving the intimate bond he has created with them.

The moral disengagement cues consist in guiding the reader's interpretation and manipulating her emotions. These cues can be of a structural or a more linguistic nature. For instance, there are no follow-up scenes to the murders (no funerals staged, no tearful widows, parents or kids that could have tilted the viewer's sympathy for the victim and against the murderer). Furthermore the asides guide the reception of such acts by foregrounding certain aspects that facilitate the moral disengagement process and by 'burying' others Underwood wants the audience to 'shallow process' (Sanford \& Emmott 2012, Emmott \& Alexander 2014). ${ }^{12}$ Frank pushes Zoe Barnes under the Metro - she is a journalist he has been having an affair with, whom he gets rid of because she refuses to abandon her investigation of Peter Russo's death in which she (rightly) suspects Frank was involved. His first comment about it to the viewers consists in controlling their potential reaction to the murder through an imperative, directive form:

Don't waste a breath mourning Miss Barnes. (2.14)

\footnotetext{
${ }^{10}$ If they are used to seeing bad guys series, they would develop a schema determining 'character roles' and 'plot expectation' without any passage through moral evaluation. Raney (2004) shows that viewers indeed tend to be efficient at defining these roles and expectations through mental shortcuts without delving first into moral issues.

${ }^{11}$ In the genre of political series, darker representations have followed The West Wing (NBC, 1999-2006) such as Boss (Starz, 2011-2012), Political Animals (ABC, 2012), Veep (HBO, 2012), or Scandal (ABC, 2012-) in the US for instance or, in Europe, the German Die Affäre Semmeling (ZDF, 2002) and Kanzleramt (ZDF, 2005) or the British parody The Thick of It (BBC, 2005-2012). House of Cards must be seen as part of this darker evolution.

12 If italics or broken sentences are some of the ways details can be fore/backgrounded in written fiction (see Emmott \& Alexander 2014 for other devices), in a "stylistics and film" perspective (Toolan 2014), there can be no such visual markers. However, naming, topicalisation or sentence ordering can also be used orally, along with cinema-specific elements like the tone of voice or the music that may also have foregrounding effects.
} 
The surnaming of the victim (Miss Barnes) rather than 'first naming' a character the viewer has become familiar with is significant. This naming choice is a stylistic distancing strategy often used in first-person serial killer narratives, as examined in Gregoriou (2011: 100), to prevent sympathizing with the victim. The protagonist goes on by asserting a reversal in agency:

Every kitten grows up to be a cat. They seem so harmless at first, small, quiet, lapping up their saucer of milk. But once their claws get long enough, they draw blood, sometimes from the hand that feeds them.

The blame is put on the ungrateful, undeserving victim who ends up being the one to whom criminal agency is ascribed: the transitive material process ('draw blood') draws attention to the violent ambitious victim, 'backgrounding' the real criminal agency. Viewers' empathy is drawn away from the innocent pet/kitten (closer to the human pole on Langacker's 1991 animacy hierarchy ${ }^{13}$ ) towards the de-anthropomorphised uncivilised blood-hungry tomcat. By downgrading Zoe to the level of the wild animal, Frank Underwood presents the victim as deserving her fate, thereby concealing his own primary guilty act. Bringing to the foreground Zoe's behaviour allows him to 'bury' his own responsibility for killing her at the very moment she discovers his criminal act.

The same animalising technique is applied to another victim of his machinations (although he has so far spared this one): The Secretary of State, Catherine Durant, has decided to turn her back on Frank because of the latter's scheming behind her back to have Claire Underwood stand for running mate in the upcoming presidential elections, instead of her, as initially announced. Violently threatening her into obedience when she dared confront him and stubbornly stand her ground, the frightened Catherine finally gets back into line. The following aside occurs after one tense encounter when Catherine agrees to do as the president says:

Frank: After a dog's bitten you, you either put it to sleep, or you put a muzzle on it. I've chosen a muzzle for now. (4.50)

The blame is ascribed to the 'dog' which has committed the first unforgivable act of biting. The animal analogy in reference to Catherine's stubborn resistance conveys the negative image of an ill-mannered, untamed dog, reversing the polarities in terms of blame by foregrounding the Secretary of State's infidelity. The aside even gives the impression she should be thankful to the bitten agent for showing (temporary) leniency ("I've chosen a muzzle for now"). As Gregoriou (2011: 94) shows in serial killer narratives, the way victims are sometimes stylistically represented can diminish killers' responsibility: "the victims are the ones that 'decide', that make 'fatal mistakes' and 'bad choices'; the killer's murderous acts are merely subsidiary to what the victims do themselves".

The use of figurative language featuring animal agents to refer to human beings is symptomatic of Frank Underwood' way of disguising questionable acts. This "burial" of facts that might attract moral scrutiny also takes the form of specific syntactical devices and cognitive tactics that the next section will delve into.

\footnotetext{
${ }^{13}$ Langacker's 1991 empathy hierarchy goes as follows: speaker $>$ hearer $>$ human $>$ animal $>$ physical object > abstract entity, which means that one feels more empathy for a human (to the left) than for an object (at the end of the line to the right).
} 


\subsection{Detachability: aphorism and humour}

A second strategy that is likely to bring the viewer to practise moral disengagement is the recurrent use made by Underwood of proverb-like utterances. In written texts, sententious aphorisms often appear as detached from the text or at least embody what Maingueneau (2012: 11) calls "textual salience" with different functions and effects: these autonomous utterances are both in the text (they contribute to the argumentation) and out of it as they are foregrounded against the rest of the text by their specific pragmatic status, as if proffered on "another scene" (Maingueneau 2012: 35). Transferred to the visual medium, the "detached" utterances are staged on the ontologically autonomous scene that the asides provide to the protagonist. A similar effect of detachability is thus created in these pseudo proverbs allowing him to take some distance from the diegetic world he comments on. The linguistic distancing has a moral disengagement effect that this section will evidence.

The proverb-like utterances are usually in the non-deictic a-temporal present tense that marks a rupture from the deictic centre the protagonist embodies in the diegesis. These asides interrupting the flow of the story line seem to be true at all times and for anyone (beyond any specific naming), hence the use of 'someone' in the following quotes:

Power is the old stone building that stands for centuries. I cannot respect someone who doesn't see the difference. (1.1)

Moments like this require someone who will act, who will do the unpleasant thing, the necessary thing. (1.1)

Once someone is exposed, they're at your mercy. (1.11)

Any pugilist worth his salt knows when someone's on the ropes. (1.19)

Such utterances allow the protagonist to hoist a subjective situation to the level of an objective fact that is 'stabilised' by the archaic grammar of the proverb. They give him the position of the expert teacher who can generalize situations to make them appear as necessarily true. Similarly, rather than naming specific individuals, the indefinite article establishes classes of people:

What a martyr craves more than anything is a sword to fall on, so you sharpen the blade, hold it at just the right angle and then... (1.2)

There's no better way to overpower $a$ trickle of doubt than with $a$ flood of naked truth.

As we used to say in Gaffney, never slap $a$ man while he's chewing tobacco. (1.9)

Shake with your right hand, but hold $a$ rock in your left. (1.18, my emphases)

As Maingueneau (2012: 22) puts it, the author speaking in aphorisms is a man who "gains height", adorning himself with the "ethos of an authorized man" asserting valuable thoughts for the whole community. Here through these 'pseudo' sayings based on proverbial wisdom with an undeniable captatio benevolentiae efficiency, ${ }^{14}$ Francis

\footnotetext{
14 These pithy, brief and memorable utterances are indeed thesaurised by fans on internet and thus "detached" from the protagonist who himself tries to detach himself from the diegetic world as if it were a stage and him the omnipotent stage director.
} 
Underwood converts himself into an authoritative source that allots him the position of the superior master. If the asides often use the generic second-person pronoun (see Sorlin 2015, 2016 on the different referential nature of the pronoun), these apparently universal sayings in fact conceal a deeply subjective way of perceiving the world, sheltering the author behind a veil of charismatic wisdom whose function and effect are to foreground him as a figure of authority and trust.

The syntactic "archaism" of the proverbs can also be counterbalanced by colloquial graphic lexemes that conversely bring the matter down to earth:

Conscience has an unmistakable stink to it, sort of like raw onions and morning breath. But a lie stinks even more when it's coming from someone who isn't used to lie. It's more like rotten eggs and horseshit. (4.46)

This aside ironically commenting on General Brockart's conscience during his conversation with Underwood in the Oval Office contains all the linguistic properties of a proverb: it begins with the zero article that brings it to a universal level ( $\varnothing$ conscience). It also features the indefinite article in 'a lie' which should be taken as an extraction from the class of lies it represents. The person referred to (the General accused of leaking classified information to Conway, Frank's Republican opponent in the run-off to the 2016 presidential election) is de-personalised as 'someone', elevating the subjective situation on which the protagonist gives his opinion to an objective truth conveyed in a performative way. Yet the grammatical mould of the pseudo-aphorism is undermined by the physical images of 'raw onions' and 'morning breath' and the orality of the formula 'sort of', 'it's more like'. The rise and fall in register from a lofty sententious formula to the coarseness of 'rotten eggs' and 'horseshit' punctuating the aside, reflects the stylistic versatility of a character daring to break both moral and linguistic normative rules. Within the same utterance, he mixes registers that he shows an apt control of - this seems to be a characteristic of antiheroes' ambiguous identities (see Schubert 2017), reinforcing the ethos of the thrilling adaptable performer. This humour-inducing daring familiarity and transgressive incongruity might be appealing to audience members.

Mirth in House of Cards is indeed another strategy of detachment that distracts the viewer from attempting to see through Frank's apparent universal truths, thus taking her away from close moral examination. In the following scene, Frank is in the White House corridor where the portraits of presidents of the Unites States hang on the walls.

Now, Conway has a powerful gun, a search engine. And it's powerful because with it, he can tell what you think, what you want, where you are and who you are. He can turn all those searches into votes, and that's enough bullets to kill my chances of winning. But I have an even bigger gun. It's called the NSA. It's one of the perks of being president. That is, if the courts allow my surveillance request. I imagine the men hanging on these walls wished they'd had a gun like that available to them.

Your phone, the phone of the person sitting next to you, your neighbour's phone and everyone you know and the 300 million Americans you don't know. I can see you, and I can use what I see to rig this election. Now, of course, a weapon like that, well, you can imagine how risky it is.

Huh, it might have even given pause to an old crook like him [pointing to Nixon]. I mean, they roasted him on the spit for tapping into a few rooms at the Watergate. I'm talking about tapping into every single home in America. And a weapon like that could blow up in my hand and that's why it's plan B. Plan A is much safer. Expose that Conway is using his gun illegally and remove the weapon from his hand.

Hmm All three of us took bullets [pointing to Kennedy and Reagan]. 
Well, [looking in Reagan's direction] I know why we're smiling.

We survived. (4.46)

He both inscribes himself within the historical presidential lineage, thus legitimizing his status and also jokes about the reasons why some smile, others do not in a most irreverent manner. The humorous ending cue "I know why we're smiling, we survived" trusts the audience's capacity to grasp the historical hints, which is likely to be gratifying for them as part of an 'in-group' community who can identify the historical references and paintings. The protagonist's sense of dark humour generates comic relief that may detach the viewer further away from the seriousness of plan B in ethical terms. He is indeed informing the viewer of his plans A and B to destroy his opponent's digital tool a search engine that can keep Conway informed of public preferences. His own device as part of the president's 'perks' that will make it possible to tap into every home is not presented as a morally questionable but as a dangerous plan if it leaks.

On the contrary, in the presence of the paintings of previous presidents, he presents this as an opportunity that the other presidents certainly would have liked to have: "I imagine the men hanging on these walls wished they'd had a gun like that available to them". In his capacity of lightening things up, he construes what amounts to amoral and illegal behaviour as a cynical game that any president would have liked to play were they born in the same 'cognitive war' digital times. Presenting his plan as a risky 'game' (see section 1), he is sharing some of the responsibility of plan B with the audience through the 'you' address ("as you can imagine"). He also makes Nixon appear as a player who is not within his abilities or audacity: "Huh, it might have even given pause to an old crook like him. I mean, they roasted him on the spit for tapping into a few rooms at the Watergate". This is likely to bring the audience to smile at the way he dares put things in perspective, backgrounding the amorality of his act by foregrounding instead how it would outstrip Nixon's transgression by far, adding up to the image of the fearless singular superhero.

So Frank authorises himself through a 'rhetoric of certainty', daring to present unethical acts as daring moves that no previous president has tried, burying ethical consideration through humour. However what makes this ethical distancing possible and keeps the viewer rooting for him is also what structurally condemns him. The last section explains why.

\section{A structurally-doomed antihero}

The number of the asides in word count varies across the five seasons (see Table 1), the first season counting the highest number of interventions on the part of the protagonist as he introduces the new political world to the viewer. By contrast in season 3 , the 'contact' with the audience is reduced - one internet fan even claiming feeling 'neglected' in that season. ${ }^{15}$

\begin{tabular}{|ll}
\hline First season: & 2,616 words \\
Second season: & 877 words
\end{tabular}

15 "I don't think we got enough of Frank breaking the 4th wall in this season. I felt a little neglected towards the last few episodes" (my emphasis) Retrieved from https://www.reddit.com/r/HouseOfCards/comments/2xf4m2/season_3 discussion thread/, date accessed 2 December 2016. 


\begin{tabular}{ll|} 
Third season: & 665 words \\
Fourth season: & 1,176 words \\
Fifth season : & 1,791 words \\
& \\
Table 1: Asides (word count per season)
\end{tabular}

Season 3 corresponds to a time of high tension between Frank and his wife, Claire, who ends up breaking up with him, jeopardizing his chances of becoming president - she will come back on equal terms in season 4 where the PSR between the media performer and the audience is re-established. The reduced number of direct addresses in season 3 affects the PSR constructed in the first two seasons, all the more so as for the first time other dissenting voices are heard like that of Freddy - who used to run a rib joint Frank very often took refuge in and who is now working as a garden-keeper in the White House. So far the viewer has always assumed Freddy found the presence of the famous politician in his joint somehow gratifying but season 3 reveals he cannot stand the president. Back in the rib joint he could at least "walk back in the kitchen when [he] got tired of hearing him talk" (3.37). This "explicit characterisation cue" 16 regarding the president by another character offers a new vantage point from which to assess the superpowerful extraordinary superhero, highlighting how manipulated the (meta)recipient ${ }^{17}$ has been so far, by and through the PSR. One can measure the extent to which the asides embody a closed space of persuasion, serving Frank's propaganda that is underpinned by the specific strategies of engagement and detachment detailed above - engagement with the character's goal and plans, and detachment from moral consideration.

Season 3 reveals the precariousness of the "para-social relationship" between the media performer and the audience. If the protagonist manipulates the viewer into following him in spite of his questionable acts, the manipulator is himself manipulated by the "collective sender" who controls the nature and degree of the PSI. Dynel's 2011 chart (see figure 1 below) makes visible the two levels involved in TV producing/viewing, the first level being the diegetic level where interactions between participants (possibly involving a third party) occur, potentially in the presence of bystanders and eavesdroppers. Level 2 feature the ratified recipients (those whom the show is for).

\section{$<$ PLEASE INSERT FIGURE 1 HERE $>$}

However to account for the specificity of the double manipulation just mentioned in House of Cards, another level must be added to the diagram (see figure 2). If the first level remains the same, the second level embodies the ontologically different space of the aside which frames Frank Underwood as a media performer commenting on the diegetic world he is also a part of - like a homodiegetic narrator in fiction, to use

\footnotetext{
16 "Explicit characterisation cues" occur when characters present other characters (or themselves) whereas "implicit" cues require inferences from the reader (Culpeper 2001: 164).

17 Dynel (2011: 1633) defines metarecipients as reviewers, university scholars or "film zealots" who take time to comment on films/TV series. I am adding parentheses to (meta)recipients to encompass both the metarecipients and other recipients who might not take the analysis as far but are part of what can be defined as "real" (as opposed to constructed) recipients for whom the series is meant, thus responding to/reacting to the authors' diegetic choices.
} 
Genette's (1972) narratorial distinctions - and reaching out to a recipient he constructs as a confidant(e)/ co-player.

$<$ PLEASE INSERT FIGURE 2 HERE $>$

A third level must be added, occupied by the collective sender and the (meta)recipients who "play against" them in interpreting the "visual Text". Just as the protagonist's utterances are designed for the recipient's benefit, the collective sender's general design is meant for the (meta)recipients. ${ }^{18}$

Level 2 is paradoxically both what makes the attempt at engaging the viewer with the protagonist possible and what structurally condemns the attempt. The Machiavellian charismatic antihero one can admire for his boldness is structurally doomed because the true Machiavellian hero never confides. Frank Underwood is thus placed in a selfdefeating position by the collective sender, not at level 1 but at level 2 . Confiding is thus both what makes it possible for him to attract and manipulate the viewer's attention and what condemns him to failure. Confessions both create an intimate PSI and reveal the antihero's cynical perspective one can enjoy but hardly 'sympathise with'. Identification, as Cohen (2001: 251) defines it, that is the adoption of the "identity" and "perspective" of the character, entailing a "loss of self awareness" is rendered structurally impossible by the 'you' address which keeps reminding the viewer of her own status as viewer, bringing her to see Level 1 and Level 2 at once. The I/you dyad precludes any total identification with the 'I' - as it can sometimes occur in first-person written narratives for instance - the 'you' address that the viewer is invited to project herself into positions her as a mere follower, a 'you' that is kept separate from the ' $\mathrm{I}$ '.

Furthermore in the fourth and fifth seasons, ethics and morality are back in the picture. The noose is tightening around Frank's and Claire Underwood's necks. A competing "text-world" 19 is gaining momentum in the fourth season as journalists gather evidence showing Frank's illegal implication in the impeachment of former President Garret Walker. A new deictic centre over which the media performer has no control concurrently evolves for the (meta)recipient to process in parallel. As shown in figure 3 below, there is no protagonist-narrator at level 2 in the second text-world (TW2). In season 4, the collective sender gives viewers better and longer access to TW2, increasingly foregrounding ethical voices that President Underwood has so far been able to stifle.

\section{$<$ PLEASE INSERT FIG 3 HERE $>$}

In the first seasons, fans seem to follow the protagonist, if only as an act of Freudian denial, as by this internet fan defending herself: "even if Frank is a villain, I feel like I'm supposed to be on his side [...] I dunno, I kind of love that the show isn't just interested in showing you the story but actively involving you in it'". ${ }^{20}$ Whatever the ethical

\footnotetext{
${ }^{18}$ Dynel (2011: 1635) drives a wedge between the collective sender's level and the recipients' as "it can hardly be argued that the recipient consciously interacts with the collective sender". Although this "interaction" is mediated by the Text, the (meta)recipient can become conscious of the collective sender's choices and manipulation, as evinced below.

${ }^{19}$ Although using a different lay-out in my figures (adapted from Dynel 2011), I'm borrowing here the convenient notion of text-world from Text World Theory: a textual world is the fictional world coconstructed by producers and recipients. It corresponds to the mental representations that are built up by the readers/viewers' minds from the Text (Gavins 2007: 10).

${ }^{20}$ retrieved from http://www.giantbomb.com/forums/off-topic-31/house-of-cards-season-2-discussionthread-spoilers-1472254/, date accessed 16 March 2018.
} 
scruples the (meta)recipient may have about rooting for the 'bad' guy are likely to strengthen in season 4 - all the more so as, backed into a corner, the protagonists have reached a new level of violence. They declare in the final aside with which season 4 ends: "We don't submit to terror, we make terror" (4.52). The use of the first person plural is exclusive here: it excludes the viewer but includes Claire Underwood who changes participatory status. She is given access to Level 2; for the first time she makes visual contact with the recipient in the last scene where the couple's look betrays their determination to destroy all resisting forces. The couple's wicked attitude is now past camouflage and justification.

However, what is likely to keep the audience involved in the series at this stage is wanting to find out how far the protagonists are allowed to go, unpunished, by the collective sender in Season 5 that was released at the end of May 2017. In the final season to date, Claire is allowed verbal access to the recipients at level 2 in text-world 1: she is granted two asides of 45 words. This sharing of aside space between the couple heralds the beginning of the fall of the male character as season 5 ends with Claire's not taking her husband's call, looking at the camera, strongly saying: "My turn". This new para-social interaction with Claire differs from the relation of trust and confidence her husband had developed, as her first aside attests:

Just to be clear, it's not that I haven't always known you were there. It's that I have mixed feelings about you. I question your intentions and I'm ambivalent about attention. But don't take it personally. It's how I feel about most everybody. (5.63)

Bringing viewers to switch from the position of co-partner in a game to that of distrusted (acknowledged) recipients, the collective sender keeps them in suspense as to what footing they will be on in this new, woman-controlled relationship (especially as the male protagonist played by Kevin Spacey will not be featured in the sixth season).

\section{Conclusion}

This paper has tried to evince the reasons why viewers may root for the antihero in spite of (or maybe because of) his immoral and illegal behaviour, highlighting how the asides contribute linguistically, cognitively and pragmatically to immerse the audience's attention in a plot-based schema that generates suspense as regards the Underwoods' achievement of their life-time goal. The imposed para-social interaction frames the viewer as a co-partner in the quest through asides justifying the protagonist's moves (in the name of superior objectives), foregrounding the victims' responsibility while backgrounding his own in order to foster moral disengagement. Detachability from petty details is also ensured by assertive pseudo-aphorisms enhancing the utterer's expertise and authority as well as by (cynical) humour used by Frank to release tension and distract attention. However, the para-social relationship between the media performer and the audience varies in intensity across the seasons as the collective sender manipulates the manipulator by pulling competing strings that affect the relation, first by giving more space to a text-world 2 in which journalists are trying to gather evidence of Frank's numerous crimes and second by giving centre stage to his wife who takes over power after Frank resigns from the presidency (without telling anyone, neither the audience nor Claire). She ends up refusing to officially pardon him, leaving him on his own as she addresses the viewer in the oval office declaring her time has come. Season 6 (whose release date is yet to be confirmed by Netflix at the time of 
writing) will reveal what kind of 'paracommunication' the collective sender chooses to establish between the audience and the newly appointed first woman president.

* corresponding author: Sandrine Sorlin, Aix Marseille University, France. Email: sandrine.sorlin@univ-amu.fr

\section{References}

Allbritton, David W. \& Richard J. Gerrig. 1991. Participatory responses in text understanding. Journal of Memory and Language 30. 603-26.

Benveniste, Emile. 1966. Problèmes de linguistique générale. Paris: Gallimard.

Brown, William J. 2015. Examining four processes of audience involvement with media personae: Transportation, parasocial interaction, identification, and worship. Communication Theory 25. 259-283.

Cialdini, Robert B., Richard J Borden, Avril Thorne, Marcus Randall Walker, Stephen Freeman, \& Lloyd Reynolds Sloan. 1976. Basking in reflected glory: Three (football) field studies. Journal of Personality and Social Psychology 34. 366-375.

Cohen, Jonathan. 2001. Defining identification: A theoretical look at the identification of audiences with media characters. Mass Communication \& Society 4(3). 245-264.

Culpeper, Jonathan. 2001. Language and Characterisation. People in Plays and Other Texts. Harlow: Pearson Education.

Dobbs, Michael. 1989. House of Cards. London: Harper Collins.

Egidi, Giovanna and Gerrig, Richard. 2006. Readers' experiences of characters' goals and actions. Journal of Experimental Psychology: Learning, Memory and Cognition 32(6). 1322-1329.

Emmott, Catherine \& Mark Alexander. 2014. Foregrounding, burying and plot construction. In Peter Stockwell \& Sara Whiteley (eds.), The Cambridge Handbook of Stylistics, 329-343. Cambridge: Cambridge University Press.

Festinger, Leon. 1957. A Theory of Cognitive Dissonance. Evanston, IL: Row \& Peterson.

Gavins, Joanna. 2007. Text World Theory: An Introduction. Edinburgh: The University of Edinburgh Press.

Genette, Gérard. 1972. Figures III. Paris: Seuil.

Gerrig, Richard J. 1993. Experiencing Narrative Worlds. On the Psychological Activities of Reading. New Haven, Conn.: Yale University Press.

Gregoriou, Christiana. 2011. Language, Ideology, Identity in Serial Killer Narratives. London, New York: Routledge.

Green, Melanie C. 2004. Transportation into narrative worlds: The role of prior knowledge and perceived realism. Discourse Processes 38. 247-266.

Green, Melanie C. \& Timothy C. Brock. 2000. The role of transportation in the persuasiveness of public narratives. Journal of Personality and Social Psychology 79. 701-721.

Green, Melanie C. \& Timothy C. Brock. 2002. In the mind's eye: Transportation imagery model of narrative persuasion. In Melanie C. Green, Jeffrey J. Strange \& Timothy C. Brock (eds.), Narrative Impact: Social and Cognitive Foundations, 315-341. Mahwah, NJ: Erlbaum.

Hartmann, Tilo. 2008. Parasocial interactions and paracommunication with new media characters. In Elly A. Konijn, Sonja Utz, Martin Tanis, Susan B. Barnes (eds), Mediated Interpersonal Communication. New York: Routledge, 177-199. 
Hartmann, Tilo \& Peter Vorderer. 2010. It's okay to shoot a character: Moral disengagement in violent video games. Journal of Communication 60(1). 94-119.

Horton, Donald \& Richard R. Wohl. 1956. Mass communication and parasocial interaction: Observations on intimacy at a distance. Psychiatry 19. 215-229.

House of Cards. 2013-, Season 1 (13 episodes, released 1 February 2013), Season 2 (13 episodes, released 14 February 2014), Season 3 (13 episodes, released 27 February 2015), Season 4 (13 episodes, released 4 March 2016), Season 5 (released 30 May 2017). Network: Netflix. Writers: Beau Willimon, Michael Dobbs, Andrew Davies (among others). Directors: Robin Wright, David Fincher, James Foley, Joel Schumacher, Charles McDougall.

Krakowiak, K. Maja \& Mina Tsay. 2011. The role of moral disengagement in the enjoyment of real and fictional characters. International Journal of Arts and Technology 4. 90-101.

Krakowiak, K. Maja \& Mary Beth Oliver. 2012. When good characters do bad things: examining the effect of moral ambiguity on enjoyment. Journal of Communication 62. 117-135.

Langacker, Ronald W. 1991. Foundations of Cognitive Grammar: Descriptive Application, Vol. 2. Stanford, CA: Stanford University Press.

Maingueneau, Dominique. 2012. Les phrases sans texte. Paris : Armand Colin.

McIntyre, Dan. 2008. Integrating multimodal analysis and the stylistics of drama: A multimodal perspective on Ian McKellen's Richard III. Language and Literature 17. 309-334.

Dynel, Marta. 2011. 'You talking to me?' The viewer as a ratified listener to film discourse. Journal of Pragmatics 43. 1628-44.

Mikulincer, Mario \& Phillip R Shaver. 2009. An attachment and behavioral systems perspective on social support. Journal of Social and Personal Relationships 26. 7-19.

Merton, Robert K. 1946. Mass Persuasion: The Social Psychology of a War Bond Drive. New York, NY: Harper \& Brothers.

Oatley, Keith. 1994. A taxonomy of the emotions of literary response and a theory of identification in fictional narrative. Poetics 23. 53-74.

Psycho. 1960. Director: Alfred Hitchcock. Screenplay by Joseph Stefano.

Raney, Arthur A. 2004. Expanding Disposition Theory: Reconsidering character liking, moral evaluations, and enjoyment. Communication Theory 14(4). 348-369

Rapp, David N. \& Richard J. Gerrig. 2006. Predilections for narrative outcomes: the impact of story contexts and reader preference. Journal of Memory and Language 54. 54-67.

Sanford, Anthony J. \& Catherine Emmott. 2012. Mind, Brain and Narrative. Cambridge: Cambridge University Press.

Schubert, Christoph. 2017. Constructing the antihero: Linguistic characterisation in current American television series. Journal of Literary Semantics 46(1). 25-46.

Shafer, Daniel M. \& Arthur A. Raney. 2012. Exploring how we enjoy antihero narratives. Journal of Communication 62.1028-1046.

Simpson, Paul. 2014. Just what is narrative urgency. Language and Literature 23(1): 322.

Sorlin, Sandrine. 2015. Breaking the fourth wall: The pragmatics of the second person pronoun in House of Cards. In Laure Gardelle \& Sandrine Sorlin (eds), The Pragmatics of Personal Pronouns, 125-145. Amsterdam: John Benjamins.

Sorlin, Sandrine. 2016. Language and Manipulation in House of Cards. A Pragma-Stylistic Perspective. Basingstoke: Palgrave Macmillan. 
Stever, Gayle S. 2013. Mediated vs parasocial relationship: An attachment perspective. Journal of Media Psychology 17(3). 1-31.

The Social Network. 2010. Director: David Fincher. Producers: Scott Rudin, Dana Brunetti, Michael De Luca, Ceán Chaffin. Screenplay by Aaron Sorkin.

Toolan, Michael. 2014. Stylistics and film. In Michael Burke (ed.), The Routledge Handbook of Stylistics, 455-470. London, New York: Routledge.

Zillmann, Dolf \& Joanne R. Cantor. 1972. Directionality of transitory dominance as a communication variable affecting humor appreciation. Journal of Personality and Social Psychology 24. 191-198.

Zwaan, Rolf A. 1999. Situation models: The mental leap into imagined worlds. American Psychological Society 8(1). 15-18. 